\title{
Tidal Volume
}

National Cancer Institute

\section{Source}

National Cancer Institute. Tidal Volume. NCI Thesaurus. Code C111324.

The volume of air moved into and out of the lungs during breathing at rest. 